\title{
The reflection paedagogy of Vasyl Sukhomlynsky and Janusz Korczak
}

\begin{abstract}
Bogusław Śliwerski, The reflection paedagogy of Vasyl Sukhomlynsky and Janusz Korczak. Interdisciplinary Contexts of Special Pedagogy, no. 27, Poznań 2019. Pp. 99-115. Adam Mickiewicz University Press. ISSN 2300-391X. e-ISSN 2658-283X. DOI: https://doi.org/10.14746/ikps.2019.27.05
\end{abstract}

The subject of the analysis is the paedagogical thought of the leading representatives of the new education movement in Poland and in the Ukraine. The timeless character of their reflection paedagogy was exemplified by the orphans' home of Warsaw, Poland, and the School of Joy in Pavlysh, Ukraine, the organisational solutions, rules of (self-)education, the system of social and moral standards bound educators the same way as they did those under their care. The phenomenon of the radical, unique approaches to supporting children, which they created, is a challenge for coming generations. With this work, I also open up the debate and the need for further research concerning the origins and consequences of transgression of state borders by paedagogical thought that constantly changes its approach to humanist paidocentric paedagogy in a world, in which authoritarian, directive or instrumental paedagogy continues to have a strong presence. In this regard, I focus primarily on the similarity of thought between both these educators, indicating the differences in their approach to the child.

KEY WORDS: self-education, education, upbringing, reflection paedagogy, paedagogy of experience, new education, paidocentrism, child-focused education, experimental school, paedagogy of the heart 


\section{Introduction}

The paedagogical approaches of Janusz Korczak and Vasyl Sukhomlynsky were, in the 20th century, a type of liberal, domestic reflection on education founded on the idea of conscience and selfresponsibility, subjectivity as well as the right of the child to a worthy life and education that was very rarely seen in literature. It was only the new century which, as a result of globalisation, fruited in the publication of literature that we refer to as practical or reflection paedagogy, hence, knowledge that is inductively generated by school reformer educators, creators of alternative schools and psychologists (mainly clinical psychologists dealing with therapy) about the upbringing and education of children. Timeless, universal interpretation by further generations of the works of both paedagogues makes their thought constantly transgress all borders of countries, cultures, nations, religions, ideologies or socio-political systems. The boldness of their remarks, suggestions or warnings, the distanced discovery of own weaknesses and true successes by educators of the heart leads by its very nature to infinity and differentiation of the reception of their works. Providing others with their experiences, they give rise to emotional and moral sensitivity, to hidden instincts or paedagogical talent. At the same time, they sketch out a circle of possible questions, doubts or aporiae that are borne out of paedagogical interactions between adults and children. The radicalism of thought, consequence in action and love in feeling and embracing mutual relations with children fruit in unique memory of meetings, touching the existential core of our personality. This is a constant search for a guarantee of human (also children's) freedom and the meaning of human life that in the works of Sukhomlynsky and Korczak are characterised by the optimistic belief in the goodness of human nature, with humans able to freely create values.

The paedagogy of these two creators, however, wouldn't have survived so long in our countries, characterised by a quite conservative approach to the education of children, were it not on the one 
hand for the ever so broad, interdisciplinary studies of their thought, were it not for the popularisation of their results, the publication of their works and achievements, and, on the other hand, were it not for the intense development, following World War II, of anti-authoritarian paedagogy with subsequent generations of educators being reached by the works of such paedagogues as: Alexander Sutherland Neill (1991, 1994), Marian Bybluk (1990, 2018), Stanisław Ruciński (1988), Hubertus von Schönebeck (1991, 1994a, 1994b, 1997, 2001, 2009), Alice Miller (1991,1995, 1999, 2000), Thomas Gordon (1991, 1994, 1995), Janusz Tarnowski (1990,1993), Jadwiga Bińczycka (1997, 2009), Barbara Smolińska-Theiss (2013), Maria Łopatkowa (1992), Bogusław Śliwerski (1992, 1998, 2007). Both streams of creation of knowledge on education, hence, a unique cultural capital of paedagogy, encourage subsequent generations of researchers to uncover mechanisms of overt and covert force that gains its efficiency through the fact of being left unrecognised.

The relationship between theory and practice is formulated through islands of educational affirmation as resistance against paedagogy of force, authoritarian, directive paedagogy, and not just thanks to reconstruction and reprints of works and writings of paedagogues of the heart. Polish humanities have much in common with the achievements of Ukrainian philosophers, including philosophers of education. It is thus necessary to design common studies so as to be able to cooperate more closely in the area of science and the popularisation of the most interesting yet proven educational and school experiments. If, for Ukrainian paedagogy, the source of the culture of joy is shaping young generations that are strong through the belief in timeless ideas, thanks to which one becomes (...) happy, "finding "joy" of the heart and peace of the soul (W.G. Kremien 2007, p. 134) ${ }^{1}$, then we can boldly include the works of Polish humanists and breakthrough educators into scientific discourse.

${ }^{1}$ Except for the works To Children I give my Heart and How to Love a Child, all quotes translated into English by the translator of the original article from Polish translator's note. 


\section{The extraordinary similarity between the paedagogies of Vasyl Sukhomlynsky and Janusz Korczak}

The works of Korczak, similarly to those of Sukhomlynsky, constitute paedagogical savoir vivre. These are guidebooks, written with great artistic talent and without excess didactic pressure, on appropriate behaviour, for parents, teachers, educators or caretakers of children and youths. In their works, the two authors do not stop at the critique of education practice, but treat it as a reality that is worthy of understanding through one's own engagement in it. Wincenty Okon describes the school thought and experiment of V. Sukhomlynsky as the paedagogy of experience (W. Okon 1997, p. 202). It constitutes quite a cautious mode of thinking, liberated from excess moralising, about how educators should proceed with respect to the ones under their care so as not to violate their mutual right to freedom and a worthy life.

Both Sukhomlynsky and Korczak number among the few educators of New Education who were able to infuse scientific thought with practical thought so that one would not complicate the other. At the same time, they avoided treating upbringing as something that should be scientifically studied beforehand in order for it to be provided with a practical meaning without reference to assumptions, behaviour patterns and understanding of objectives. Their works contain neither pure scientific empirical paedagogy nor exclusively normative speculation, nor meta-theoretic deconstruction, and despite this, their views fill, sharpen, simplify or illuminate the core of paedagogical phenomena in each of these approaches to upbringing and to its theoretical or practical substantiations.

\section{The core and the objectives of education}

In the approach of V. Sukhomlynsky: Education consists first of all of continuous contact between teacher and pupil. (...) To educate children through their teachers, to teach teachers the science and art of educa- 
tion - this is important, but it is one side of the multi-faceted process of administering a school. Ifothe head teacher only instructs others in the art of teaching but has no direct contact with children, then he ceases to be an educator (Sukhomlynsky 2019, p. 33). Similarly, Korczak was opposed to paedagogism, meaning, a utopian attitude of educators towards children, shining through in the conviction of the omnipotent influence on them, of the universal power to effect education alongside the rights of individual and social development discovered by nature. He confirms it in one of his works: It is not just an empty saying, if I put it so: It is happiness for humanity if we cannot force children to submit to educational influences and didactic attacks on their healthy minds and healthy human will (Korczak 1984, p. 124).

Sukhomlynsky sought explanations of phenomena that bothered him in the development or behaviour of children in scientific studies in medicine and psychology, but he also - just like Korczak did diagnosed their family and health situations himself by way of observations, discussions with their family members, inclusion in creative activity, etc. The life of Janusz Korczak and his feat of amazing moral strength and purity is an inspiration for me - writes Sukhomlynsky I learned from him that to give children a genuine education one must give them one's heart (Sukhomlynsky 2019, p. 39). Every day, as a teacher and head teacher, he verified and analysed his knowledge, skills, achievements, successes and failures.

This served the development of new forms and methods of working with children, so as to, bringing a spiritual union with them into existence, become their friend. Direct everyday dealing with children is the source of thoughts, educational discoveries, joys, sorrows, and disillusionments. Without them, creativity is impossible in our line of work (...) Studying is important, but it is not the only thing in the life of the child. The more closely I examined all of which have come to be called the educational-upbringing process, the more convinced I became that the many-sided spiritual Life of the children's collective in which teacher and pupil are united by a multitude of interests and hobbies is the real school (Sukhomlynsky 2019, p. 35).

Hence, if we bind the moral authority of both paedagogues with their ability to seek out and communicate the truth on education, 
we shall find in their reflection the strength and power of argument not to succumb to threats or crises of the process irrespective of the circumstances that may accompany it - even in the postmodern world. Both paedagogues were able to let go of the "costume of obviousness" of conservative education science, making the conversion of the centric view on education and the persons participating in it, providing the recipients of their work with "new glasses" through which one should perceive the world of paedagogical interaction. Writing about how to love a child and on their right to respect, Korczak created in truth the paedagogy of a "new man". Sukhomlynsky similarly created a school of instilment in children primarily of love for man, respect for human dignity: The child must feel what is in the heart of the other person. Thus the important educational task I set for myself can be formulated (Sukhomlynsky 2019, p. 132). Pupils must hence be reinforced in their own self-esteem.

As is clear, the approach to education of both these educators would not have been possible without true conversion, change, without metanoia, meaning, without a mental revolution in the dominant vision of the social and education world (P. Bourdieu, L.J.D. Wacquant 2001, p. 252). The reflective insight in their paedagogical practice and thought creates one of the strongest centres of a teacher or educator being "meta", or above them, but at the same time also reflexively responsible for themselves. It is through control of perversions, pathologies, education crises (in education and following education) that they created for us resources (tools) to multiply and further develop humanistic education. Sukhomlynsky is aware of the dysfunctions of the traditional, authoritarian school and the improper attitudes of teachers with respect to pupils. In his words, using the wonderful metaphor: The teacher wants the child to answer the question, more quickly; it matters little how the child thinks-he must have an answer then and there so he can give a mark. It has never occurred to the teacher that it is impossible to speed up the flow of this slow but mighty river. Let this river flow in accordance with its nature; her waters will surely reach the destination, but don't hurry. Please don't get nervous; don't beat this mighty river with birch switches of bad marks-nothing will help (Sukhomlynsky 2019, p. 76). 
Both Korczak and Sukhomlynsky relieve us from misconceptions on education and educators. Their every step should be - as Sukhomlynsky writes - (...) our journey to the sources of thought and speech, to the miraculous beauty of nature. I would see to it that every one of my pupils grow up into a reflective and searching person, so that every step to knowledge would ennoble the heart and temper the will (Sukhomlynsky 2019, p. 62). The core of education becomes the task of guaranteeing to the young generation of worthy conditions for joyous living. It is somewhat of a preventive, but also a therapeutic, task, as it boils down to supporting the internal development of children and youths, the acquisition of self-awareness and strengthening of their independence and liberation from social, external care or welfare. Education situations should thus be characterised by oscillation between the individual shaping of personality and constructive forming of the world in a way that people would change in course of the social relations they create.

The views of Sukhomlynsky and Korczak most commonly presented in paedagogical discourse are those that expose the educational imperative of the individual approach to every child, its unique role in social life, including the particularly accented category of the natural rights of the child, which, in the ontological perspective, are identical to the rights of adults. Indeed, a child cannot be an addition to adult lives, much less the object of their manipulation, but a self-contained force and value that must be reckoned with. Both oppose generalisation, absolutisation of children in general, as in truth, the process of education always concerns dealing with a specific individual.

\section{Sources of paedagogical anthropology of paedagogues of the heart}

The paedagogical anthropology of both Sukhomlynsky as well as Korczak was borne out of the deeply humanistic conviction that the child, just like an adult, is an autonomous value and possesses the same right to be an author of their live, to self-determination 
and self-creation, as every adult person does. The first one concludes: Self-education plays an enormous role in one's life. A person educated in the full sense of the world can be termed one who is able to educate themselves (Sukhomlynsky 1982, p. 23). We thus have the perspective of education as a process that concludes with the ability of the student to take over the capacity to direct themselves. Korczak also expresses this rule with an appeal to educators: Be yourself - seek your own way. Get to know yourself before you are able to get to know children. Become aware of what you are able to do, before you commence to describe for children the scope of their rights and duties. Of everyone, you are a child that you foremost have to get to know, educate and bring up (J. Korczak 1984, p. 217). He questions not as much as the ability of the student to self-educate, but even that of the educator who, setting such a goal for those under his care, could not achieve it themselves. Hence, anybody who is not able to educate themselves, guide their development, be their own master, cannot educate to self-education.

Following Pestalozzi, whose idea of self-education was very much valued by Korczak, he reinforces its challenge for the argument of bilateral self-honing, a sort of permanent work on themselves carried out by own people, so that in this way they could retain their status of autonomy and individuality. Being yourself, being true to oneself, is a necessary condition of all human existence, irrespective of many biological and social conditions. He expresses it much more strongly with his conclusion: We desire of our children to be better than us. We dream of the perfect person of the future. We have to carefully catch ourselves in the act of lying, pin down the egotism disguised as a cliche. (...) Forgiven, we have given up in the fight with ourselves, burdening our children with it. The educator is quick to take on the privilege of an adult: see to the children, not to oneself, register not own faults, but the children's (J. Korczak 1984, p. 80). In both these educators, this is a sine qua non condition of possible education of the child on the condition that the educator educates themselves. Sukhomlynsky turns to future parents directly: You son, should continue to educate yourself, you should educate and prepare your children. (Sukhomlynsky 1982, p. 97). 
Sukhomlynsky, however, disagrees with Korczak when he writes: We forget that every human being, born as a person, is not a person yet. It has to be shaped to be a person (A. Sukhomlynsky 1982, p. 13). At the same time, the "Old Doctor" expressed, undaunted, the opinion that it is one of the ugliest errors to believe that paedagogy is a science dealing with the child, and not - with man. (...) There are no children - there are people; but they do have a different scale of concepts, a different level of experience, other cravings, a different game of emotions (J. Korczak 1984, p. 217). Both are teachers of life, of sharing humanly love, respect for the dignity of another and feeling their experiences and emotions, but in addition - each of them separately stresses either education in duty or education in respect for children's rights (J. Korczak 1984).

The publications of Sukhomlynsky exhibit timeless dilemmas of natural and professional educators. He asks: How to develop in the child a love for learning? How to counter or oppose evil that grows in the behaviour and attitudes of a teenager? What to do when children cease to believe in good and humanity? How to bring them up? How to find harmony between parental love and caring on the one hand and the requirements of a child? How to proceed in order for children to be happy, if the school does not prepare them for this? Paedagogy of the heart fits in perfectly with this scope of expected change. The children should become people with a clear reason, a noble heart, golden hands, and elevated feelings. (...) It is the job of the school and the parents to give every child happiness - multi-faceted happiness - happiness so the child can discover its abilities, learn to love labour, and to work creatively to be able to enjoy the beauty of the world around it, and to create beauty for others, to love other people, to be loveable, to be genuine human beings. Only the common efforts of parents and teachers can give children great happiness (Sukhomlynsky 2019, p. 58).

When Sukhomlynsky writes about preparing young people for motherhood and fatherhood, he exposes the category of responsibility: The human being develops best in fulfilment of duties. In one taking responsibility for another. Duty, duty and more duty - this is the atmosphere in which one should bring up an entity that was born as a person in 
order for it to be able to be referred to by the noble designation of a Person (A. Sukhomlynsky 1982, p. 17). For Korczak, however, to impose duties on a child is against the organisation of its spiritual life. We burden them with the duties of tomorrow's man, without giving them any rights of today's person (J. Korczak 1984, p. 150).

The way Sukhomlynsky perceives children, describes them and writes about them, is truly captivating, as it reflects the truth of parental pain but also the beauty of life with children, thanks to their presence, for them and for ourselves. Korczak writes similarly: Bringing a child up is not a fun game, but a task that takes the effort of sleepless nights, the collection of hard experiences, and much thought (J. Korczak 1984, p. 102). To bring a child up means at the same time to bring oneself up. The act of education and self-education is perceived by both paedagogues fully, meaning, in its bidirectional reaction, when both processes intertwine. The dialectic unity of inseparable phenomena is doubtless broader and deeper in its dimension and understanding than the unilateral relationship described earlier.

A broader aspect of this act entails the fact that the unsubstantiated division into the educator and student is removed from it. Sukhomlynsky comments: At any moment, looking at your child, you see yourself. Bringing your child up, you also bring yourself up and elevate your human dignity. (...) The beautiful side of this activity is that one finds within it joy that can be compared to nothing (W. Sukhomlynsky 1982, p. 18). The richness of issues that unsettle the educator, in Korczak's works as well, should facilitate the establishment of own reflection on what they should improve and amend around themselves, as well as within themselves. An educator who does not learn from his students loses contact with them, and quickly descends into routine.

Both paedagogues are proponents of paedagogy of the heart. Sukhomlynsky asks: How to love? And responds: There exists a dangerous disease - indifference of the heart. Look into your soul, whether there is even a tiny seed of this malady there? If it jest - throw it away, do not let weed sprout. Indifference of the heart - is indifference of man (Sukhomlynsky 1982, p. 24). Just like Korczak responding to the 
question: How to love a child, and is love not a merit for which the educator would demand compensation? - he concludes that one needs to primarily let the child live its own life and be authentic towards them. You want to be loved by children, but you have to force them into tight, stuffy forms of contemporary life, contemporary deceit, contemporary force - through diligent, dutiful, imposed work. They do not want this, defend themselves, they must bear a grudge against you. (...) You have to set an example (J. Korczak 1984, p. 218).

Reading the views of Sukhomlynsky on bringing a child up in the family, and analysing the works of Korczak we can surprisingly conclude how much they had in common. The paedagogy of the heart of one, and the paedagogy of love and respect for the child of the other - finds within their statements almost identical rules of upbringing. Sukhomlynsky shares his conviction (...) that the highest wisdom of parental love rests in how we fathers and mothers are able to show to children the true sources of the joy of life, in which the children see and feel the joy of being (Sukhomlynsky 1982, p. 37). For him, the joy of a child cannot be derived from their egotistical drives to be fulfilled by parents or grandparents, as they will grow up to become a "stone-hearted child".

Hence, the love for a child cannot be depriving in the spirit of sensitivity or hypertrophy of the heart. If parents repeat to their children at every step the rule: "You are the hope of our lives" - the children will grow the conviction that they do us a great deed taking from us tangible and intangible goods (ibidem, p. 40). Contemporary clinical psychology describes this type of overbearing parental attitudes towards children as toxic, and for Sukhomlynsky, they are a sign of languid despotism of primitive parents. The education errors of parents can still be repaired by the school, educating children in wise love, instilling in them sensitivity of the heart towards the surrounding world, through work, through the experience of satisfaction from one's enterprise for the good of those closest and others. Not playing work, but actual work, with its sweat, fatigue, toil, rest and joy in the achievement of the goal - is guard enough of human conscience (...) (ibidem, p. 62). 
Janusz Korczak approaches the conditioning of a child's joy similarly, admonishing parents in his short work "How to love a child" using the following words: If you can assess the child's rejoicing and its intensity, you will readily notice that the supreme joy is that of a difficulty surmounted, a goal attained and a mystery uncovered, the exaltation of triumph and the happiness of independence, proficiency and power. (...) Why is he so happy to blow out a match, to carry the father's slippers or to bring grandma's footstool? Is it just mimicry? No, it is something much bigger and more precious. "I can do it myself" - he shouts a thousand times by gesture, eyes, smile, entreaty, anger and tears (J. Korczak 1984, p. 131). Do we not see in this approach of both paedagogues to education with the heart and wise love reflections of also other educators of New Education, such as Ellen Key, Èdouard Claparède or Maria Montessori? Is it not the first generation of reflecting, humanistic educators, three of whom were educated doctors who considered the sense and efficiency of the process of education from the point of view of the child, but in a dual relation with it - of their educators - parents, teachers, etc.?

After the conclusion of the 20th century, not fulfilling the expectations of Ellen Key as the Century of the Child, we instil the imperative of love and care for the psychological, physical and spiritual development of every person, and children in particular, not only in the environment of their family lives, but also their school and professional lives. It was Èdouard Claparède who asked in his sketch of 1901, entitled "A School to Fit", for it to respect the free development of the child, its intellectual and moral personality, adapting it to anyone just like a tailor sewing bespoke clothing. Why should we not have the same respect for the soil as we do for the torso, head or legs? (È. Claparède 2005, p. 37). Sukhomlynsky also writes of the need for multi-faceted perception of everyone, because (...) every side shines through in its entire beauty if we only look at it skilfully and precisely (...) The dreading complexity, the entire difficulty and joy of upbringing, if one asks me, entails finding this side of theirs in every person (Sukhomlynsky 1982, p. 95). Expresses this statement in one of his studies: The child is not a lottery ticket, set to win their painting at City Hall or a bust in the 
theatre's foyer. Everyone has their own spark that can set alight fires of joy and truth, perhaps in the tenth generation it will explode with a blaze of genius and burn its family away, giving the light of a new sun to humanity (Korczak 1984, p. 139).

\section{Conclusion}

Authors of scientific publications refer ever more frequently to the most dramatic challenges of the contemporary world, such as the dehumanisation of politics, education and interpersonal relations, the progressing destruction of the environment and neverending wars. The vantage point for the discourse on contemporary education are most frequently chosen to be the current threats or perils. The education of man, even a religious person, is a big issue today. Some believe that everything depends on the educators, others - just the opposite - believe that educators cannot influence anything. Even if the end of the family, education or school teaching, as professed by political scientists and sociologists, did not transpire yet, but for most researchers of these socialisation environments it is without a doubt that they are becoming ever less efficient, pathogenic and they do not fit in with the quick, sometimes radical changes that are occurring around these.

The dilemma of leaving behind the crisis of education is subordinated to the search for responses to many questions: To what extent does this process have a future anyway? What constitutes the meaning of education in daily inter-generational relations? Can the world still be changed through the restoration of values in education? The case does not entail the dramatisation of the conditions of daily lives in the categories of creation of the ultimate (normative) chance at human survival, but analysing whether it is possible to thoughtfully describe conditions that would guide both individuals as well as social groups towards worthy lives in the three most important areas for education - our one (common) world, ecology and peace? 
The phenomenon of the crisis is dual in character. One could describe the crisis in the negative sense, as a sort of breakdown, worsening of a specific state of affairs, its downfall, decay or threat, and in the positive sense, as a sort of breakthrough, extreme, turning point, announcing desirable changes, an exit from turmoil. Scientists agree that if in the near future there is no radical and common change in human conscience in the area of values, attitudes and activities, then our world will suffer ecological destruction, leading to global hazards for life. The more global the issues are, the less can an individual do, however, the less one changes their lifestyle in this regard, the quicker the destruction of the Earth progresses. We are living in a society in which people are allowed to understand, control or shape on their own their environments of life to an ever lesser extent. At the same time, however, man wants to expand the scope of their experiences and conscience more and more.

It is worth analysing, what in particular does the process of globalisation bring if it also touches upon children and youths, if it itself is in a crisis? To what extent can paedagogy of the heart allow us to become enriched by reflection on the possibilities of finding our place in the world becoming so small for everyone, even if it is not within arm's reach for everyone? Some are divided by globalisation, others united in something. To what extent does this process start up additional factors of marginalisation with respect to children, and to what extent does it facilitate their development? To what extent does globalisation concern the situation of children in the world? Can one see both its negative and positive factors?

Hence, the key message of both paedagogues of reforms, paedagogues of the heart, is - irrespective of the ideas and value of different school cultures and education thoughts permeating our societies to turn attention to the period of early childhood, in which the foundations of humanity of every person are shaped, and in course of early education - the meaning of learning "with the open heart" throughout the entire life, but also the experience of joy from work. Luckily, knowledge on education and upbringing of various nations and their philosophical or psychopaedagogical models is not the sub- 
ject of commercial transactions or economic pressure, hence, the profit of global corporation owners or leaders of the richest countries of the world. It does, however, affect cultural and education confrontations as well as the contradictions with deeply cultural, religious and world-view national factors that emerge in the race for the new.

Education actively participates in the destruction of symbols, traditions and of own culture due to the education policy of nation states, if it forgoes one's own cultural code, questions the national spirituality, departing from one's own history, language and tradition. The globalised individual, racing for success, does not waste time, which is money, on disquiet over their inner life. Such a person is dominant not only in the contemporary civilisation, but is also the origin of the virtual-globalised man, leading to unification and entropy of personality, spirits, languages, independence, national identity (Kremień 2007, p. 181). It is also worth noting that Christian globalisation, fusing numerous and diverse cultural and religious communities, even though it strives to balance the spiritual dimension in society with the civic one, succumbs - as W. Kremień writes - as a result of pragmatisation of social conscience - to gradual perversion and de-Christianisation of over two thousand years of European civilisation. In the Ukraine one still has the consciousness of the need to care for high culture that was the dominant factor in national paedagogy. If one thus speaks about the need for reforms in this country, then most likely in the spirit of homocentrism, hence, the philosophy of the heart that opposes paedagogy of oppression. In Poland, this thought returns as governance is taken over by right-wing political parties, which include proponents of both paedagogy of the heart, spiritual paedagogy, as well as oppressive and authoritarian paedagogy.

\section{Bibliography}

[1] Bińczycka J. (1997), Między swobodą a przemoca w wychowaniu, Kraków, Oficyna Wydawnicza "Impuls”.

[2] Bińczycka J. (2009), Spotkanie z Korczakiem, Olsztyn, Olsztyńska Szkoła Wyższa im. Józefa Rusieckiego. 
[3] Bourdieu P., Wacquant L.J.D. (2001), Zaproszenie do socjologii refleksyjnej, transl. by Anna Sawisz, Warszawa, Oficyna Naukowa.

[4] Bybluk M. (1990), Radosna szkoła Suchomlińskiego, Warszawa - Toruń, Wydawnictwo Edytor.

[5] Bybluk M. (1998), Przemiany edukacji w Rosji u schyłku XX wieku, Studia i szkice historyczno-pedagogiczne, Torun, Wydawnictwo UMK.

[6] Bybluk M. (2003), Przemiany demokratyczne edukacji w Rosji, Kraków: Oficyna Wydawnicza „Impuls”.

[7] Bybluk M. (2011), Innowacje i eksperymenty pedagogiczne „okresu przełomu”. Doświadczenia radzieckie, rosyjskie, ukraińskie, Bydgoszcz, Wydawnictwo Kujawsko-Pomorskiej Szkoły Wyższej w Bydgoszczy.

[8] Bybluk M. (2019), Wasyl Suchomliński i jego najpopularniejsze dzieło, [in:] W. Suchomliński, Oddaje serce dzieciom, transl. into Polish by M. Bybluk, Brzezia Łąka, Wydawnictwo Poligraf.

[9] Claparède È. (2005), Szkota na miarę. Odczyt wygłoszony w auli Uniwersytetu Genewskiego z ramienia Niezależnego Komitetu Reformy Szkolnictwa, transl. by Z. Ziembiński, Warszawa, Wydawnictwo Akademickie "Żak".

[10] Gordon T. (1991), Wychowanie bez porażek, transl. by A. Makowska, E. Sujak Warszawa, IW PAX.

[11] Gordon T. (1994), Wychowanie bez porażek w praktyce, transl. by E. Sujak, Warszawa, IW PAX.

[12] Gordon T. (1995), Wychowanie bez porażek w szkole, transl. by D. Szafrańska-Poniewiewrska, Warszawa, IW PAX.

[13] Korczak J., How to Love a Child, accessible at <http://www.januszkorczak. $\mathrm{ca} /$ legacy/3_How to Love a Child.pdf>.

[14] Korczak J. (1984), Pisma wybrane, Introduction and selection by A. Lewin, vol. I, Warszawa, Nasza Księgarnia 1984.

[15] Kremień W. (2007), Filozofia edukacji, transl. by Igor Rodiuk, Radom, Instytut Technologii Eksploatacji - Państwowy Instytut Badawczy.

[16] Łopatkowa M. (1992), Pedagogika serca, Warszawa, WSiP.

[17] Miller A. (1991), Mury milczenia. Cena wyparcia urazów dzieciństwa, transl. by J. Hockuba, Warszawa, WN PWN.

[18] Miller A. (1999), Zniewolone dzieciństwo. Ukryte źródła tyranii, transl. by B. Przybołowska, Poznań, Media Rodzina.

[19] Miller A. (1995), Dramat udanego dziecka. Studia nad powrotem do prawdziwego Ja, transl. by N. Szymańska, Warszawa, Wydawnictwo J. Santorski.

[20] Miller A. (2000), Ścieżki życia. Historie, w których każdy odnaleźć może własne losy, transl. by A. Gierlińska, Poznań, Media Rodzina.

[21] Neill A.S. (1991), Summerhill, transl. by B. Bialecka, Katowice, Wydawnictwo Almaprint.

[22] Neill A.S. (1994), Nowa Summerhill, transl. by M. Duch, Poznań, Wydawnictwo Zysk i S-ka. 
[23] Ruciński S. (1988), Wychowanie jako wprowadzanie w życie wartościowe, 2nd revised edition, Warszawa, Wydawnictwa Uniwersytetu Warszawskiego.

[24] Schoenebeck H. von (1991), Antypedagogika w dialogu. Wprowadzenie w rozmyślanie antypedagogiczne, transl. by Dorota Sztobryn, introduced and edited by B. Śliwerski, Toruń, Wydawnictwo UMK.

[25] Schoenebeck H. von (1994a), Antypedagogika. Wspierać zamiast wychowywać, transl. by Natasza Szymańska, Warszawa, Jacek Santorski \& CO Agencja Wydawnicza.

[26] Schoenebeck H. von (1994b), Kocham siebie takim jakim jestem. Antypedagogiczna filozofia życia, transl. by: Iwona Pańczakiewicz; sc. ed. by B. Śliwerski, Kraków, Oficyna Wydawnicza „Impuls".

[27] Schoenebeck H. von (1997), Po tamtej stronie wychowania. Życie w wolności od psychicznej przemocy, transl. by E. Pastuszek, W. Żłobicki, Kraków, Oficyna Wydawnicza "Impuls".

[28] Schoenebeck H. von (2001), Szkota z ludzka twarza. Wizja i rzeczywistość, transl. by A. Murzyn, Kraków, Oficyna Wydawnicza "Impuls”.

[29] Schoenebeck H. von (2009), Postpedagogika. Od antypedagogiki do Amication, transl. by A. Murzyn, Kraków, Oficyna Wydawnicza „Impuls”.

[30] Smolińska-Theiss B., Korczakowskie narracje pedagogiczne, Kraków, Oficyna Wydawnicza „Impuls” 2013.

[31] Suchomliński W.A. (1982), Kilka słów o wychowaniu, transl. by Wacław Bielecki, wstęp: Aleksander Lewin, Warszawa, WSiP.

[32] Suchomliński W. (2019), Oddaje serce dzieciom, transl. by M. Bybluk, Brzezia Łąka, Wydawnictwo Poligraf.

[33] Sukhomlinsky V., To Children I give my heart, translated from Russian by Holly Smith, available at <http://www.arvindguptatoys.com/arvindgupta/Va sily.pdf $>$.

[34] Śliwerski B. (1992), Przekraczanie granic wychowania. Od 'pedagogiki dziecka' do antypedagogiki, Łódź, Folia Paedagogica et Psychologica.

[35] Śliwerski B. (1998), Wspótczesne teorie i nurty wychowania, Kraków, Oficyna Wydawnicza "Impuls”.

[36] Śliwerski B. (2007), Pedagogika dziecka. Studium pajdocentryzmu, Sopot, GWP.

[37] Tarnowski J. (1990), Janusz Korczak-dzisiaj, Warszawa, Wydawnictwo ATK.

[38] Tarnowski J. (1993). Jak wychowywać?, Warszawa, Wydawnictwo ATK. 